\title{
Resistance to Rhynchosporium commune in a collection of European spring barley germplasm
}

Mark E. Looseley, Lucie L. Griffe, Bianca Büttner, Kathryn M. Wright, Jill MiddlefellWilliams, Hazel Bull, Paul D. Shaw, Malcolm Macaulay, Allan Booth, Günther Schweizer, Joanne R. Russell, Robbie Waugh, William T.B. Thomas, Anna Avrova

M. E. Looseley, L. L. Griffe, K. M. Wright, J. Middlefell-Williams, H. Bull, P. D. Shaw, M. Macaulay, A. Booth, J. R. Russell, R. Waugh, W. T.B. Thomas, A. Avrova The James Hutton Institute, Invergowrie, Dundee, DD2 5DA, Scotland, UK E-mail: mark.looseley@hutton.ac.uk; anna.avrova@hutton.ac.uk

B. Büttner, G. Schweizer

Bavarian State Research Center for Agriculture, Institute for Crop Science and Plant Breeding, Am Gereuth 2, 85354 Freising, Germany

Present Address:

L. L. Griffe

RAGT Seeds Ltd, Grange Road, Ickleton, Saffron Walden, Essex, CB10 1TA, UK H. Bull

Syngenta UK Ltd, Market Stainton, Market Rasen, Lincolnshire, LN8 5LJ, UK

Key message: Association analyses of resistance to Rhynchosporium commune in a collection of European spring barley germplasm detected 17 significant resistance quantitative trait loci. The most significant association was confirmed as Rrs1. 


\begin{abstract}
Rhynchosporium commune is a fungal pathogen of barley which causes a highly destructive and economically important disease known as rhynchosporium. Genome wide association mapping was used to investigate the genetic control of host resistance to $R$. commune in a collection of predominantly European spring barley accessions. Multi-year disease nursery field trials revealed 8 significant resistance quantitative trait loci (QTL), whilst a separate association mapping analysis using historical data from UK National and Recommended List trials identified 9 significant associations. The most significant association identified in both current and historical data sources, collocated with the known position of the major resistance gene $\operatorname{Rrs} 1$. Seedling assays with $R$. commune single spore isolates expressing the corresponding avirulence protein NIP1 confirmed that this locus is Rrs 1 . These results highlight the significant and continuing contribution of Rrs 1 to host resistance in current elite spring barley germplasm. Varietal height was shown to be negatively correlated with disease severity, and a resistance QTL was identified that co-localised with the semi-dwarfing gene $s d w 1$, previously shown to contribute to disease escape. The remaining QTL represent novel resistances that are present within European spring barley accessions. Associated markers to Rrs 1 and other resistance loci, identified in this study, represent a set of tools that can be exploited by breeders for the sustainable deployment of varietal resistance in new cultivars.
\end{abstract}

Keywords: barley, rhynchosporium, resistance, Rrs1, QTL, GWAS 


\section{Introduction}

Barley (Hordeum vulgare L.) is the fourth most widely grown cereal crop, that was cultivated on over 49 million hectares worldwide and produced 141 million tonnes of grain in 2016 (faostat.fao.org). Whilst most barley is used as a carbohydrate source in animal feed, approximately $20 \%$ of worldwide production is processed. The majority of this is used for malting in order to produce alcoholic drinks.

Fungal pathogens represent the main constraint to barley production, with the fungal pathogen Rhynchosporium commune causing one of the most economically significant and destructive diseases of barley worldwide (reviewed in Avrova and Knogge 2012). This disease is known as rhynchosporium, barley scald, or leaf blotch. Whilst its primary significance is through severe decreases in yield, with losses of up to $40 \%$ when conditions are favourable for disease development (Xi et al. 2000), it can also affect grain quality traits through a reduction in grain size (Khan and Crosbie 1988) leading to increased grain nitrogen content and screenings (the proportion of grains passing through a set sieve size). $R$. commune has been classified as a hemibiotroph (Perfect and Green 2001; Oliver and Ipcho 2004); despite producing necrotic lesions, it has a long asymptomatic phase during which it is able to colonise the subcuticular region of the epidermis and even sporulate (Zhan et al. 2008; Thirugnanasambandam et al. 2011; Avrova and Knogge 2012). R. commune is a polycyclic pathogen, with primary inoculum coming either from crop debris or infected seed (Davis and Fitt 1992; Fitt et al. 2010). Agronomic practices such as seed treatment, crop rotation, tillage and grazing are important ways of controlling the occurrence of the disease, by limiting primary inoculum (Arvidsson 1998; Elen 2002). Secondary inoculum is formed by conidia produced on infected leaves, which spread infection up the plant by splash dispersal (Fitt et al. 1988). The primary method of disease control in the field is through fungicide application. However, $R$. commune is a highly genetically diverse pathogen (Zaffarano et al. 2006) and has developed insensitivity to previously effective fungicide classes, e.g. methyl benzimidazole carbamates and demethylation inhibitors (Taggart et al. 1999; Avrova and Knogge 2012).

Varietal resistance is another effective way of providing protection against initial infection and is an important and sustainable method of disease control. Major resistance $(R)$ genes trigger plant defence responses by directly or indirectly recognising the products of avirulence genes expressed by the pathogen during infection. However, due to the simple genetic architecture of this interaction, major gene mediated resistance can be broken down 
after only a short period of commercial cultivation (Newton et al. 2001; Abang et al. 2006), unless the avirulence gene product is essential to the pathogen. An example of this is the mutation or loss of the avirulence gene NIP1, under the strong selective pressure of Rrs 1 carrying cultivars which are able to recognise NIP1 (Rohe et al. 1995; van't Slot et al. 2007).

A number of studies have reported partial resistance that reduces rhynchosporium severity (Williams and Owen 1975; Xue and Hall 1991; Kari and Griffiths 1993; Schweizer and Stein 2011; Looseley et al. 2012). As partial resistance relies on less specific interactions with the pathogen, it is likely to be more durable (Poland et al. 2009), but the limited magnitude of the effect of partial resistance genes means that they are unlikely to provide sufficient levels of varietal resistance if used in isolation. Increasing the effectiveness of these various crop protection tools is likely to be achieved through adopting an integrated approach to disease management, using a combination of fungicides, agronomic practices and varietal resistance. The use of resistant cultivars carrying polygenic, and therefore more durable, resistance (both $R$ genes and quantitative resistance) with complementary effects is the most sustainable and cost effective method of protecting the considerable breeding effort required to identify and incorporate resistance genes into elite cultivars (Walters et al. 2012). However, due to the difficulty of distinguishing between the effects of alternative resistance genes (particularly with epistasis) the generation of polygenic resistance is problematic for commercial breeders using only phenotypic selection, and as such, there is a requirement, not only for new sources of resistance, but also for the identification of closely linked, or diagnostic markers for marker assisted breeding.

Several major resistance genes and quantitative trait loci (QTL) against $R$. commune have already been mapped. Rrs 1 on 3H (Hofmann et al. 2013), Rrs2 on 7H (Hanemann et al. 2009), Rrs4 on 3H (Patil et al. 2003) and Rrs15b on 2H (Schweizer et al. 2004) originated from Hordeum vulgare, but wild Hordeum species have also been used as a source of resistance. Rrs12 on 7H (Abbott et al. 1992), Rrs13 on 6H (Abbott et al. 1995), Rrs14 on 1H (Garvin et al. 2000) and Rrs15a on 7H (Genger et al. 2003; Genger et al. 2005) were first described in crosses with resistant $H$. spontaneum accessions, while Rrs 16 on 4H (Pickering et al. 2006) was introduced from $H$. bulbosum. So far, none of these genes have been cloned.

The first resistance locus mapped was Rrs1 on 3H (Backes et al. 1995; Thomas et al. 1995 ) and to date more than 11 alleles have been described (Bjørnstad et al. 2002; Hofmann et al. 2013) leading to a debate over whether Rrs 1 is a complex locus comprising multiple tightly linked genes, or different alleles of the same $R$ gene. The functional effect of Rrs 1 seems to be 
the prevention of penetration and subcuticular growth (Lehnackers and Knogge 1990; Carisse et al. 2000; Thirugnanasambandam et al. 2011) of $R$. commune isolates carrying avirulent allele of NIP1 (Rohe et al. 1995). NIP1 is an avirulence protein, which does not trigger the hypersensitive response (HR) during plant pathogen interaction (Hahn et al. 1993). It has been shown to interact with the barley plasma membrane $\mathrm{H}^{+}$-ATPase independently of the barley genotype suggesting that at least one extra genotypically dependant mechanism is involved in activating the resistance, such as another protein or a conformational change of the target, induced by NIP1 interaction with plasma membrane (van't Slot et al. 2007).

Genetic and genomic resources for barley have developed rapidly over recent years, with simple and effective genotyping platforms available at a variety of scales (Moragues et al. 2010; Comadran et al. 2012). In addition, a high quality reference genome assembly has now been made available (Mascher et al. 2017). These resources have allowed Genome Wide Association Studies (GWAS) to be used for identifying loci affecting quantitative traits in barley with the potential to identify candidate genes (Cockram et al. 2008; Comadran et al. 2012). GWAS studies allow significant genetic diversity to be sampled in a single experiment, as well as providing high resolution QTL information (Waugh et al. 2014), and have successfully been used in barley to identify associations with resistance to Fusarium head blight, net form net blotch, spot form net blotch, stem rust, spot blotch, and leaf rust (Massman et al. 2011; Zhou et al. 2014; Ziems et al. 2014; Tamang et al. 2015; Richards et al. 2017).

The aim of the current study was to identify and map QTL influencing resistance to $R$. commune in cultivated north-western (NW) European spring barley. In order to identify robust associations, a complementary set of contemporary and historical field trial data were used to validate marker associations and to identify field resistances that retain effectiveness against current pathogen populations. A further aim was to use single isolate teste to validate highly significant associations and characterise these resistance effects. Markers associated with QTL identified in this study will allow cost-effective improvements in resistance against this important barley pathogen.

\section{Materials and methods}

\section{Disease nursery trials}

A collection consisting of 660 lines of spring barley was tested in field trials at the rhynchosporium disease nursery at the James Hutton Institute's Invergowrie site near Dundee 
in Scotland. This collection was collated from lines included in the Biotechnology and Biological Sciences Research Council (BBSRC) funded IMPROMALT project BB/K008188/1, and the ERA-PG-funded project ExBarDiv (Xu et al. 2018), and predominantly represented diversity across current and historical NW European spring barley accessions. Disease assessments were conducted over the course of three growing seasons (2013-15) with the majority of lines (73\%) present in all three trials, and a large majority (95\%) present in at least two trials. For each of the trials, two replicates were sown using a randomized row and column design. Trials were sown as either $1.5 \mathrm{~m}^{2}$, or $3 \mathrm{~m}^{2}$ plots using a sowing rate of either 120 or 333 seeds $/ \mathrm{m}^{2}$ respectively (Table S1). Continuous growing of barley in the disease nursery had resulted in considerable build-up of inoculum so that natural infection occurred and was encouraged by application of overhead irrigation on alternate days. Visible disease symptoms were assessed according to the method described by Looseley et al (2015). Briefly, plots were scored on a 1-9 scale, where 1 represented complete absence of disease symptoms and 9 a complete coverage of the non-senescent leaf area by lesions. Disease symptoms were assessed 2-3 times per season. In the 2014 and 2015 trials, average height to the base of the ear was measured after stem extension had ceased. A standardised area under the disease progress curve (AUDPC) of each plot was calculated for all trials (Simko and Piepho 2012). Details of trials and timing of disease and height assessments are provided in Table S1.

For each trial, line means were estimated using GenStat 18 software (VSN International 2011) by comparing different REML mixed models. In each case, the fixed model comprised the barley line, and the random model included replicate. For more complex models, additional terms accounting for spatial effect were added to the random model. These included row and column effects as well as a residual term accounting for their interaction. The VSTRUCTURE procedure was used to specify a correlation model for the spatial terms using either a $1^{\text {st }}$ order autocorrelation or identity structure. REML models were compared using a likelihood ratio test to compare the effects of adding in row and column effects in all combinations to the basic randomised complete block model: the simplest model for which there were no significantly better models was used to estimate line means.

Estimated means from each year were standardised following the formula $Z=(x-\mu) / \sigma$ where $\mathrm{x}$ is the estimated mean of the line, $\mu$ is the mean of the population and $\sigma$ is the standard deviation of the population.

Shapiro-Wilk tests for normality testing, correlation test and one way analysis of variance were run using GenStat 18 software (VSN International 2011). 


\section{Historical disease scores}

In the UK, value for cultivation and use (VCU) is assessed for new cultivars prior to inclusion on the National List (NL) in a series of trials coordinated by the British Society of Plant Breeders (BSPB). The best of these lines are then entered into the Agriculture and Horticulture Development Board (AHDB) Cereals and Oilseeds division Recommended List (RL) trials, the results of which are used by AHDB to recommend cultivars to grow to farmers. Rhynchosporium disease severity is assessed as percentage disease cover of the upper leaves due to natural infection in trials that have not been treated with fungicides as part of both the NL and RL trial protocols. The rhynchosporium disease scores for the period 1990-2014 were collated from the NL and RL trials as part of the IMPROMALT project BB/K008188/1. Cultivars included in this data set were present in these trials for a variable number of years (mean 3.9 years, range 1-23 years). For each year, data was collected from between 4 and 22 trial sites. Best Linear Unbiased Predictors (BLUPs) of the means for each cultivar were calculated using the REML directive in Genstat 18, using a random model consisting of site (nested within year); trial series (RL or NL); genotype; genotype by year interaction; and genotype by site interaction. The final data set consisted of BLUPs for 364 cultivars (Table S2).

\section{Genotypes and genetic map}

Genotypes for a subset of the lines, for which phenotypic data was available, were generated using the $9 \mathrm{k}$ barley iSelect SNP genotyping platform (Comadran et al. 2012). This comprised a total of 595 lines of which 364 had historical phenotypic data, and 499 had disease nursery scores. Of the genotyped lines, 301 had both historical and disease nursery phenotypic data (Table S2). Within each subset, SNPs with greater than 20\% missing, together with those having a minor allele frequency of less than $10 \%$ were excluded from further analysis in order to provide robust marker trait associations. The final marker set used for the GWAS comprised 4580 SNP markers for disease nursery trials, and 4377 SNP markers for the historical data set. The R package, LPmerge, was used to merge IBSC, PopSeq and BOPA maps (MuñozAmatriaín et al. 2011; Mayer et al. 2012; Ariyadasa et al. 2014) into a single consensus map (Xu et al. 2018). 


\section{GWAS}

For lines with 9k genotypes and disease nursery scores, multiple environment association analyses, treating years as environments, were performed in GenStat 18 using the QMASSOCIATION procedure. Population structure was accounted for using an Eigen analysis, with significant PCA scores being included as random term. The first two principal components from an overall analysis of the 601 lines, which had both genotypes and phenotypes, are shown in Figure S1. The VCMODEL option was used to select the best variance/covariance matrix model for environments (years) according to the Schwarz information criterion, this was the compound symmetry model in each case, indicating that variances and covariances were correlated across years.

For lines with 9k genotypes and RL/NL mean rhynchosporium scores, a single environment association analysis was conducted using the QSASSOCIATION procedure of Genstat 18, again using an Eigen analysis to correct for population structure, with significant PCA scores being included as a random model term.

\section{QTL identification}

For the analysis using historical phenotypic data and a single environment GWAS, the effective marker matrix dimensions were used to derive a significance threshold (- $\left.\log _{10} p\right)$ of 3.2 for a genome wide significance level of 0.05 using the 'THRMETHOD' option of the QSASSOCIATION procedure. The same absolute threshold was used for the multienvironment GWAS of AUDPC scores, but was increased to 5 for the height scan to reflect the higher median inflation factor for this trait, and in order to restrict candidate QTL to only the most significant associations. Associated markers were considered as part of distinct QTL if sets of markers with significances greater than the threshold were separated by an interval greater than $+/-10 \mathrm{cM}$ from a peak marker as described by Tondelli et al. (2013).

\section{Location of previously reported resistance genes}

Information about previously mapped major resistance genes, and other genes reported to affect $R$. commune resistance, including their flanking markers was collated from the literature. The flanking markers were used to locate the major resistance genes on the iSelect map used in this study. For studies that used markers that were not represented on the iSelect map, marker or primer sequences were used in a BLASTn search with default settings against the Morex reference assembly (Mascher et al. 2017). These positions were used to identify flanking 
iSelect markers with known physical positions, allowing genetic intervals to be identified for the current map.

For QTL associated with previously reported major genes (where the published interval was less than $25 \mathrm{cM}$ ), historical trends in QTL were investigated by comparing allele frequencies for peak markers for QTL against the year for which cultivars were first entered for UK NL trials. Cultivars were divided into 8 sets, grouped by date of introduction, and the frequency of the allele associated with the resistant phenotype of the peak QTL marker calculated.

\section{Single spore isolate tests}

Seedling resistance screens with $R$. commune isolates avirulent on barley lines containing Rrs 1 were performed. Multiple isolates were used as most isolates are avirulent on multiple major resistance genes. These screens used spray inoculation and visible disease scoring with single spore isolates LfL12F and R214, and a detached leaf assay with $R$. commune strain T-R214GFP, a green fluorescent protein (GFP) expressing version of isolate R214, (Thirugnanasambandam et al. 2011) in combination with confocal microscopy.

A seedling spray inoculation assay using R. commune isolate LfL12F (avirulent on Rrsl, Rrs2 and Rrs13) was conducted as described in Schweizer et al. (1995) with modifications to assess symptoms development. Briefly, four seeds per test line were sown in 9x9 cm pots. Pots were kept at $18^{\circ} \mathrm{C}$ with $16 \mathrm{~h}$ light per day. Three weeks after sowing (late 3 leaf stage (DGS 13-14) (Tottman 1987)), plants were spray inoculated with a spore suspension $\left(2 \times 10^{5}\right.$ spores $/ \mathrm{ml}$ ) and kept at $16^{\circ} \mathrm{C}$ in the dark at $100 \%$ humidity for $48 \mathrm{~h}$. Subsequently, plants were kept at $16^{\circ} \mathrm{C}$ with $16 \mathrm{~h}$ light. Symptoms were assessed on a $0-4$ scale with 0 representing no visible symptoms, 1 for very small lesions on edge and tip of leaf, 2 for small defined lesions on edge and basis of leaf, 3 for big, confluent lesions on the whole leaf and 4 for total collapse and drying-out of the leaf (Figure 1) (Jackson and Webster 1976). 66 European spring barley lines, predicted as carrying an allele conferring resistance (18 lines) or susceptibility (48 lines) at the Rrs 1 locus, based on results from the GWAS analysis, were screened, supplemented by: 2 Spanish landraces SBCC154 and SBCC145, carrying Rrs $1_{R h 4}$ (Hofmann et al. 2013); spring barley cultivar Pewter, carrying Rrs2 (Hanemann et al. 2009), and the winter barley cultivar Retriever, likely to be carrying Rrs 1 (Looseley et al. 2015). Scores at 16 days post inoculation (dpi) were used to determine resistance or susceptibility. Overall scores were recorded for each of the four seedlings and means calculated for each line. Lines with mean score of 2 and higher 
were considered susceptible. For 4 of these lines, a $2^{\text {nd }}$ seedling assay using isolate R214 (virulent on $\operatorname{Rrs} 2$, but not on $\operatorname{Rrs} 1$ ) was conducted according to the same protocol.

For the detached leaf assay 3-5 plants of each selected line were grown for 2-3 weeks until the emergence of the $3^{\text {rd }}$ leaf in a glasshouse at $17^{\circ} \mathrm{C}$ under $16 \mathrm{~h}$ day length. Detached leaf assays were performed as described in Newton et al. (2001). Briefly, rectangular polystyrene boxes $(79 \times 47 \times 22 \mathrm{~mm}$ ) (Stewart Solutions) were filled with approximately $20 \mathrm{ml}$ of $0.5 \%$ water agar with $0.8 \mathrm{mM}$ benzimidazole (Sigma). Five $4 \mathrm{~cm}$ leaf segments were placed with the abaxial surface onto the set agar in each box. Leaves were brushed using a sable hair paintbrush to remove some of the cuticle waxes, to prevent water droplets sliding off the leaf surface. The abraded area of each leaf was inoculated with $10 \mu \mathrm{l}$ of spore suspension adjusted to $10^{4}$ spores $/ \mathrm{ml}$ and the boxes incubated in a controlled environment cabinet (Leec, model LT1201) at $17^{\circ} \mathrm{C}$ under $16 \mathrm{~h}$ day length. Confocal imaging of 3-5 inoculation spots was performed at 23 dpi as described in Thirugnanasambandam et al. (2011) on a Leica SP2 confocal microscope using an excitation wavelength of $488 \mathrm{~nm}$. GFP fluorescence was imaged between 505 and 530 nm. Overall 28 European spring barley cultivars predicted to have an allele conferring either resistance (14 lines) or susceptibility (14 lines)_at the Rrs 1 locus, based on results from the GWAS analysis, were screened, supplemented by the same lines (apart from Pewter) that were added to the spray inoculation assay above. Lines were qualitatively differentiated as resistant, with a restricted randomised mycelial growth, and susceptible, with extensive mycelial network outlining barley epidermal cell walls (Looseley et al. 2015). Representative images of resistant and susceptible interactions are shown in Figure 1.

Reactions against single spore isolates differential against Rrs 2 were taken from the AGOUEB project final report (Thomas et al. 2014) in order to compare these results against a QTL identified next to the $\operatorname{Rrs} 2$ interval.

\section{Results}

\section{Phenotypes}

Rhynchosporium infection occurred in each of the years over which barley accessions were tested in the disease nursery trials, with a normal distribution of AUDPC observed in all 3 years (Figure 2A-C). From the REML analysis for disease nursery trials, the effect of genotype was highly significant $(\mathrm{p}<0.001)$ in all years and for all traits. Interestingly the distribution of mean 
disease scores of the cultivars from RL/NL was skewed towards lower levels of rhynchosporium (Figure 2D), which may reflect the use of minimum standards of disease resistance in the recommendation of cultivars to UK growers by AHDB Cereals \& Oilseeds. Correlation coefficients between disease severity estimates for cultivars from RL/NL trial data and disease nursery rhynchosporium severity scores were moderate but highly significant for all disease nursery trials (Table 1).

A wide variation in mean height, ranging from 70 to $170 \mathrm{~cm}$ in 2014 and from 50 to 130 $\mathrm{cm}$ in 2015, was observed in the collection of spring barley accessions tested in the disease nursery trials (Figure 2E-F). Overall 2.4- and 2.6-fold variation for plants height was recorded in this collection of barley accessions. The height distribution was skewed towards lower height in both years (Figure 2E-F). Mean barley accession height (measured in the disease nursery trials) was significantly correlated across years and showed a moderate to weak negative correlation with all measures of rhynchosporium severity (Table 1).

\section{Marker-trait associations}

Associations between markers and disease severity were identified on all but two $(1 \mathrm{H}$ and $5 \mathrm{H}$ ) of the seven barley chromosomes from disease nursery trials (Figure 3A, Table 2). Overall, 8 QTL were identified showing significant associations with AUDPC in the disease nursery trials, 3 of these QTL are located on chromosome $3 \mathrm{H}$ (Table 2). Out of the 8 QTL, 4 showed evidence for a QTL $x$ environment $(\mathrm{GxE})$ interaction, but in no case was there evidence of significant cross-over interactions.

The single environment GWAS analysis identified 9 QTL for historical disease scores from RL/NL trials. These were located on barley chromosomes $3 \mathrm{H}, 4 \mathrm{H}, 5 \mathrm{H}$ and $7 \mathrm{H}$ (Figure 3B, Table 3).

In addition, 6 QTL were identified which showed significant associations with height in the 2014 and 2015 disease nursery trials (Figure 3C, Table 2). Three of the height QTL showed significant interactions with year (environment) but there was no evidence for significant crossover effects for any of these.

Genomic inflation was observed in each of the GWAS analyses although this was of moderate magnitude for rhynchosporium assessments (Figure 3D-E). For the analysis of height $_{2}$ the observed genomic inflation was substantially higher (Figure 3F).

For both data sources, the most significant disease severity association (QA3 and QI2) was with marker SCRI_RS_221644, located at $53.5 \mathrm{cM}$ on chromosome $3 \mathrm{H}$ with - $\log _{10}$ p scores 
of 9.9 and 6.3 respectively (Figure 3A-B, Table 2, Table 3). The minor allele frequencies (MAFs) for this marker were $12 \%$ and $17 \%$ from disease nursery and RL/NL data respectively (Table 2, Table 3). QA3 and QI2 were responsible for the largest effects on disease severity in all three years of disease nursery trials and historical disease scores from RL/NL trials (Table 2, Table 3).

From the previously published studies, flanking markers for nine major resistance genes against rhynchosporium were placed on the current genetic map, along with the semi-dwarfing gene $s d w 1$ (Figure 3A-C, Table 4). In most cases the map interval for these loci was less than $15 \mathrm{cM}$, although in the case of Rrs14 and $\operatorname{Rrs} 16$, it was approximately $20 \mathrm{cM}$, and, in the case of $\operatorname{Rrs} 13,30 \mathrm{cM}$. A number of the map intervals for these resistance loci overlapped with QTL identified in the current study. The Rrs 1 interval on chromosome $3 \mathrm{H}$ between 48.7 and 59.6 $\mathrm{cM}$ coincided with the most significant rhynchosporium resistance QTL identified from both the RL/NL means and from the disease nursery trials (Figure 3A-B, Table 2-4).

No QTL within the published interval of Rrs3 was detected in disease nursery trials, but the map interval of QI5 on chromosome 4H overlapped with the published Rrs3 interval, although it was an effect of the major allele with $59 \%$ of cultivars containing the marker allele associated with resistance (Figure 3A-B, Table 3, Table 4).

The map interval for Rrs13, located on the short arm of chromosome $6 \mathrm{H}$ included QA7, although the published interval of this gene spanned a large interval of $18.8 \mathrm{Mb}$ (Figure $3 \mathrm{~A}$, Table 2, Table 4). QA7 showed inconsistent effect over years with the strongest resistance effect, contributed by the major allele, in 2015 (Table 2). It is not clear from these results whether the QTL detected represented an effect of Rrs 13. The presence of the allele associated with resistance at high frequency since the 1970s suggests that this is not the case (Table 5).

The physical map interval of $\operatorname{Rrs} 15 \mathrm{~b}$ on chromosome $2 \mathrm{H}$ included the peak marker for QA1 which had a fairly low, inconsistent effect over years with the strongest effect in 2013 (Figure 3A, Table 2, Table 4)

The published interval of Rrs 16 spanning $\sim 19 \mathrm{cM}$ equivalent to $\sim 11 \mathrm{Mb}$ at the start of 4H coincided with QA6, detected in the disease nursery trials, which only had a significant effect on disease severity in 2015 (Figure 3A, Table 2, Table 4). In the case of QA6, the major allele was associated with resistance, with $86 \%$ of cultivars containing the marker allele associated with resistance (Table 2). The frequency of the peak marker allele associated with the resistance at QA6 increased from $33 \%$ in lines entered for NL trials in 1970-1980 to over 
$50 \%$ by 2000-2005 (Table 5). Such a high frequency yet again makes it unlikely that this resistance represents an effect of Rrs 16 introduced from $H$. bulbosum.

QI8 was located close to the published position of Rrs2. To examine whether QI8 was an effect of $\operatorname{Rrs} 2$, results from a differential isolate screen reported in Thomas et al (2014) were tested against iSelect 9k markers from the region of 7H. Whilst the peak QTL marker, 11_21419, was weakly associated with Rrs 2 resistance (Fisher's exact test: $\mathrm{p}=0.06$ ), a second marker, 11_20242, on the other side of Rrs2 interval, that was not significant in the current GWAS (that identified QI8), showed a substantially stronger association with the data from Thomas et al (2014) (Fisher's exact test: $\mathrm{p}<0.0001)$ suggesting that QI8 was not an effect of $\operatorname{Rrs} 2$ resistance.

The most significant association with height, QH4, (as measured in the 2014/2015 disease nursery trials) coincided with the published map interval of the semi-dwarfing gene $s d w 1$ (Figure 3C, Table 2, Table 4). This effect also coincided with a significant QTL for disease severity, QA5, identified in the disease nursery trials, with the allele associated with tallness also being associated with a consistent reduction in disease severity over years (Figure 3A, Table 2, Table 4). Similarly, a height effect at $47.2 \mathrm{cM}$ on chromosome $3 \mathrm{H}, \mathrm{QH} 3$, was coincidental with an effect on AUDPC, QA3, (although not the peak marker) with the allele associated with tallness also being associated with a consistent reduction in disease over three years of disease nursery trials (Figure 3A, C, Table 2).

In general there was a tendency for resistance associated alleles at peak markers for QTL co-localising with known resistance genes to increase in frequency over time, although marker SCRI_RS_138723, associated with $s d w 1$ became fixed for the allele associated with the semidwarf (susceptible) phenotype in lines recently entered in NL trials (Table 5). The marker associated with the major resistance gene $\operatorname{Rrs} 1$ showed a considerable increase in the frequency of the allele associated with resistance in cultivars released since 2005, becoming the major allele in cultivars released since 2010.

\section{Phenotyping Rrs1 resistance with $R$. commune isolates expressing NIP1}

In order to test whether or not the resistance QTL identified at the mapped position of Rrs 1 was, in fact, $\operatorname{Rrs} 1$, single-isolate screens using two NIP1 expressing isolates were conducted. A set of 22 barley lines, carrying the resistance associated allele at the peak QTL marker, and 48 barley lines, carrying the susceptibility associated allele at the peak QTL marker, were tested with isolate LfL12F. All but one line with the resistance associated marker allele were resistant 
to isolate LfL12F, and 47 out of 48 lines with a susceptibility associated marker allele were susceptible to isolate LfL12F (Table 6). Cultivar Pewter, carrying the susceptibility associated marker allele, but also known to carry Rrs2 (Hanemann et al. 2009), showed moderate resistance to isolate LfL12F. In addition to barley lines with $\operatorname{Rrs} 1, R$. commune isolate LfL12F is recognised by lines with Rrs2 and Rrs13. Therefore, we also used isolate R214 and T-R214GFP (a version of isolate R214, expressing GFP) specifically recognised by lines with Rrs 1 but not $\operatorname{Rrs} 2$, for additional testing of 17 lines with the resistance associated marker allele and 15 lines with the susceptibility associated marker allele, including cultivar Pewter. This showed that Pewter was susceptible to isolate R214 and confirmed the phenotypes obtained with isolate LfL12F for all of the other lines tested (Table 6). The combined data for 70 tested barley lines showed very strong evidence against independence (Fisher's exact test: $\mathrm{p}<0.0001$ ).

\section{Discussion}

This study used two separate sources of data, recent disease nursery trials and, historical RL/NL trials, to investigate the genetic basis of resistance to $R$. commune in a collection of predominantly European spring barley accessions. There was a substantial phenotypic correlation between the two data sources (comparable to the phenotypic correlations between years in the disease nursery trials), although only one QTL was common to both data sets. Nevertheless, this shared QTL (within the mapped position of Rrsl) showed the biggest consistent effect in both datasets and may largely explain the strength of the phenotypic correlation. There are a number of potential explanations for the differences in the QTL sets that were detected for each data source. One such explanation is that it may represent the effects of variation in pathogen population structure (in time as well as between sites) e.g. (Zhan et al. 2012). This, in itself, may reflect pathogen evolution in response to the widespread incorporation of resistance genes into elite cultivars. Similarly, whilst there was considerable overlap between the varietal sets for each data source (Supplementary Table S2), differences in the composition of each set may affect the ability to detect specific resistance effects due to difference in LD structure or allele frequencies at loci influencing resistance traits.

The consistent and, in some cases, highly significant negative correlation between varietal height and disease severity seen in these experiments supports findings from a number of previous studies that have identified the importance of plant height to field resistance to $R$. 
commune, most likely due to disease escape (Fitt et al. 1988; Looseley et al. 2012; Looseley et al. 2015), with the effect not being seen in controlled inoculations (Hofmann et al. 2013). The most significant determinant of height in this study was a QTL at the known position of the well characterised semi-dwarfing gene $s d w 1$ on chromosome $3 \mathrm{H}$. The peak marker for this QTL (SCRI_RS_138723) also showed a significant consistent association with AUDPC in the disease nursery trials, strongly suggesting that disease resistance represents a negative pleiotropic effect of the height effect at this locus. Similarly, marker 11_10601 at $47.2 \mathrm{cM}$ on chromosome $3 \mathrm{H}$ showed a significant consistent association with both AUDPC and height in the disease nursery trials. Whilst this marker was grouped with QA3, the fact that this (rather than the peak marker for QA3) showed an association with height, suggests this may represent a separate effect. Analysis of allele frequency against year of introduction for the marker associated with $s d w l$ shows that the allele associated with the semi-dwarf phenotype has become fixed in all lines entered for NL trials since 2005 and has been a minor allele since 1990. This observation likely reflects the improved agronomic performance of semi-dwarf types, but the consequence of this is increased exposure of spring crops to rhynchosporium infection through a reduction in disease escape (Fitt et al. 1988; Looseley et al. 2015), which in turn increases the importance of breeding for resistance in this crop.

The GWAS detected 17 QTL that contributed to field resistance to $R$. commune in the spring barley association mapping panel from both of the GWAS analyses. Five of these QTL locations corresponded to previously reported major resistance genes, $\operatorname{Rrs} 1, \operatorname{Rrs} 3, \operatorname{Rrs} 13$, Rrs $15 b$ and Rrs 16. Considering that majority of the cultivars used in this study are susceptible to rhynchosporium, it is highly unlikely that the resistant sources used to map these genes have been widely incorporated into spring barley breeding programmes, with the exception of Rrsl. It is, however, possible that the QTL represent alternative but much less effective alleles of these resistance loci. The published intervals for all of these resistance genes span from $11 \mathrm{Mb}$ in case of $\operatorname{Rrs} 15 \mathrm{~b}$ and $\operatorname{Rrs} 16$, equivalent to 7 and $19 \mathrm{cM}$ respectively, to $408 \mathrm{Mb}$, equivalent to $\sim 15 \mathrm{cM}$, in case of Rrs3. Therefore the QTL detected in this study are likely to represent a novel locus rather than the effect of the major resistance gene. For the disease nursery analysis, QTL effects were often consistent across years, showing no evidence for a QTL by environment interaction. Where significant QTL by environment effects were detected, these appeared to represent an absence of effect in certain years rather than a difference in the direction of the effect. This is consistent with differences in pathogen race structure between years, or an environmental effect on the expression of resistance. 
Although the collection of spring barley accessions used in this study contained several cultivars, including, Digger, Livet and Pewter, carrying Rrs2 (Hanemann et al. 2009), no QTL within the Rrs 2 interval was identified. One of the QTL identified using the historical RL/NL data, QI8, was located on the telomeric region of the short arm of chromosome $7 \mathrm{H}$, very close to the mapped position of Rrs2. Nevertheless, the observation that the peak QTL marker showed a weaker association with Rrs 2 phenotypes (taken from a previously published study) than another marker located on the other side of Rrs 2 interval, suggests that the field resistance QTL reported here represents a different effect from the previously reported Rrs2 resistance. The inability to detect $\operatorname{Rrs} 2$ resistance from either historical data or from disease nursery data might be explained by the absence of markers from Rrs 2 interval, a low frequency of the $\operatorname{Rrs} 2$ allele, or ineffectiveness of $\operatorname{Rrs} 2$ against natural $R$. commune populations following several years of deployment of Rrs 2 in barley breeding, or a combination of these effects.

For both of the phenotypic data sets used to map resistance to $R$. commune, a single marker on chromosome 3H (SCRI_RS_221644) showed the most significant association with disease scores, as well as the largest effect. In each case, the minor allele was associated with the resistant phenotype. The location of this QTL corresponds to the known position of the major resistance gene Rrsl (Hofmann et al. 2013). Single isolate tests using NIP1 expressing $R$. commune isolates were consistent with this field resistance representing an effect of Rrsl. Cultivar Pewter, with the susceptibility associated marker allele, but also known to carry $\operatorname{Rrs} 2$ (Hanemann et al. 2009), showed moderate resistance to isolate LfL12F. This is consistent with the fact that Rrs2 is known to recognise isolate LfL12F (Marzin et al. 2016) and when tested with an isolate that is virulent on Rrs2 (R214), Pewter showed full susceptibility. Although marker SCRI_RS_221644 was quite effective in differentiating between Rrs1 and non-Rrs1 barley lines, it is not a truly diagnostic marker, as cultivar Karri had an allele associated with Rrs1 but was susceptible to $R$. commune isolate LfL12F, expressing NIP1, suggesting an incomplete LD with the phenotype. Further research into characterisation of differential SNPs within Rrs 1 interval is required to identify truly diagnostic markers for Rrs 1 . Taken together, these results are strongly supportive of the interpretation that the field QTL detected here represents an effect of $\operatorname{Rrs} 1$ and supports the observation that Rrs 1 remains effective against natural $R$. commune populations made by Looseley et al. (2015) at the Dundee trial site. This is an interesting observation given that previous studies have demonstrated that $R$. commune has overcome Rrs 1 resistance by losing the expression and/or the function of the recognised form of NIP1 in 45\% of the isolates (Schürch et al. 2004). More recently NIP1 deletion mutants 
were shown to cause weaker symptoms on barley cultivars missing Rrs 1 gene suggesting the importance of NIP1 for virulence (Kirsten et al. 2012). This suggests that NIP1 expressing isolates might have an advantage over isolates missing NIPl in the field population in the absence of a constant selection on Rrs 1 expressing barley cultivars.

A comparison between the frequency of the resistance associated marker allele and the year in which cultivars were first entered into NL trials demonstrates that, whilst the resistance associated allele of marker SCRI_RS_221664 is detectable in cultivars dating back to at least the 1970s, a substantial increase in frequency has occurred since 2005, with the majority of new UK spring barley cultivars now carrying the resistant marker for this locus. This observation likely reflects direct selection for rhynchosporium resistance across this period, although it is not clear whether this is due to phenotypic selection, or from previously published genetic markers. Nevertheless, it is clear that Rrs 1 is present across a variety of current cultivars and as such is highly accessible to UK spring barley breeders. The SNP marker SCRI_RS_221664 that exhibited a high level of LD with Rrs 1 provides a valuable tool for breeders to both introduce resistance into existing breeding programmes and for initial selections.

Similarly, the other associated markers identified in this study, reflect variation that currently exists within UK elite germplasm. This genetic variation represents a resource that can be used in routine marker screening in existing spring barley breeding programmes to increase levels of varietal resistance without the additional problems caused by introgressing resistance from exotic sources. Nevertheless, the ability to detect marker-trait associations using this technique depends on the allele frequency at QTL, and therefore, it is likely that rare resistance genes were not detected by this analysis. The resistance estimates for the barley accessions described in this study are likely to also represent a useful resource for further genetic investigations of resistance in spring barley.

\section{Author contribution statement}

MEL, LLG, RW, JR and AA conceived and designed the experiments. HB collated the collection of barley cultivars. PS, MM, and AB produced the genotypic data. MEL, LLG, BB, KMW and JM-W performed the experiments. MEL, LLG and AA analysed the data. MEL, LLG, WTBT and AA wrote the manuscript. All authors read and approved the final manuscript. 


\section{Acknowledgements}

We thank the IMPROMALT Consortium for making the germplasm collection as well as the genotypic and historical phenotypic data available for this study and the BSPB and the AHDB Cereals and Oilseeds division for the provision of the National and Recommended List data. We also thank Richard Keith, Chris Warden, Dave Guy and Alfred Barth for all their technical help in this work.

This work was funded by the Scottish Government Rural and Environment Science and Analytical Services (RESAS) and the Bavarian State Ministry of Food, Agriculture and Forestry and the BMBF under grant-no 031B0199D. MEL and WTBT were also funded by the BBSRC IMPROMALT project BB/J019593/1. LLG was funded by the BBSRC training grant (BB/K501906/1). AA was also funded by the BBSRC-CIRC project BB/J019569/1.

\section{Conflict of Interests}

On behalf of all authors, the corresponding author states that there is no conflict of interest. 


\section{References}

Abang MM, Baum M, Ceccarelli S, Grando S, Linde CC, Yahyaoui AH, Zhan J, McDonald BA (2006) Pathogen evolution in response to host resistance genes: Evidence from fields experiments with Rhynchosporium secalis on barley. Phytopathology 96:S2

Abbott DC, Brown AHD, Burdon JJ (1992) Genes for scald resistance from wild barley (Hordeum vulgare Ssp Spontaneum) and their linkage to isozyme markers. Euphytica 61:225-231

Abbott DC, Lagudah ES, Brown AHD (1995) Identification of RFLPs flanking a scald resistance gene on barley chromosome 6. Journal of Heredity 86:152-154

Ariyadasa R, Mascher M, Nussbaumer T, Schulte D, Frenkel Z, Poursarebani N, Zhou R, Steuernagel B, Gundlach H, Taudien S, Felder M, Platzer M, Himmelbach A, Schmutzer T, Hedley PE, Muehlbauer GJ, Scholz U, Korol A, Mayer KFX, Waugh R, Langridge P, Graner A, Stein N (2014) A sequence-ready physical map of barley anchored genetically by two million single-nucleotide polymorphisms. Plant Physiology 164:412-423

Arvidsson J (1998) Effects of cultivation depth in reduced tillage on soil physical properties, crop yield and plant pathogens. European Journal of Agronomy 9:79-85

Avrova A, Knogge W (2012) Rhynchosporium commune: a persistent threat to barley cultivation. Molecular Plant Pathology 13:986-997

Backes G, Graner A, Foroughiwehr B, Fischbeck G, Wenzel G, Jahoor A (1995) Localization of quantitative trait loci (QTL) for agronomic important characters by the Use of a RFLP map in barley (Hordeum vulgare L.). Theoretical and Applied Genetics 90:294-302

Bjørnstad Å, Patil V, Tekauz A, Marøy AG, Skinnes H, Jensen A, Magnus H, MacKey J (2002) Resistance to scald (Rhynchosporium secalis) in barley (Hordeum vulgare) studied by near-isogenic lines: I. markers and differential isolates. Phytopathology 92:710-720

Carisse KX, Burnett PA, Tewari JP, Chen MH, Turkington TK, Helm JH (2000) Histopathological study of barley cultivars resistant and susceptible to Rhynchosporium secalis. Phytopathology 90:94102

Cockram J, White J, Leigh FJ, Lea VJ, Chiapparino E, Laurie DA, Mackay IJ, Powell W, O'Sullivan DM (2008) Association mapping of partitioning loci in barley. BMC Genetics 9

Comadran J, Kilian B, Russell J, Ramsay L, Stein N, Ganal M, Shaw P, Bayer M, Thomas W, Marshall D, Hedley P, Tondelli A, Pecchioni N, Francia E, Korzun V, Walther A, Waugh R (2012) Natural variation in a homolog of Antirrhinum CENTRORADIALIS contributed to spring growth habit and environmental adaptation in cultivated barley. Nature Genetics 44:1388-1392 
Davis H, Fitt BDL (1992) Seasonal changes in primary and secondary inoculum during epidemics of leaf blotch (Rhynchosporium secalis) on winter barley. Annals of Applied Biology 121:39-49

Elen O (2002) Plant protection in spring cereal production with reduced tillage. III. Cereal diseases. Crop Protection 21:195-201

Fitt BD, Atkins SD, Fraaije BA, Lucas JA, Newton AC, Looseley ME, Werner P, Harrap D, Ashworth M, Southgate J, Phillips H, Gilchrist A (2010) Role of inoculum sources in Rhynchosporium population dynamics and epidemiology on barley. HGCA Final report. Project Number RD-2004-3099.

Fitt BDL, Mccartney HA, Creighton NF, Lacey ME, Walklate PJ (1988) Dispersal of Rhynchosporium secalis conidia from infected barley leaves or straw by simulated rain. Annals of Applied Biology 112:49-59

Garvin DF, Brown AHD, Raman H, Read BJ (2000) Genetic mapping of the barley Rrs 14 scald resistance gene with RFLP, isozyme and seed storage protein markers. Plant Breeding 119:193-196

Genger R, J. Williams K, Raman H, J. Read B, Wallwork H, Burdon J, Brown A (2003) Leaf scald resistance genes in Hordeum vulgare and Hordeum vulgare ssp. spontaneum: Parallels between cultivated and wild barley. Australian Journal of Agricultural Research 54:1335-1342

Genger RK, Nesbitt K, Brown AHD, Abbott DC, Burdon JJ (2005) A novel barley scald resistance gene: genetic mapping of the Rrs 15 scald resistance gene derived from wild barley, Hordeum vulgare ssp spontaneum. Plant Breeding 124:137-141

Grønnerød S, Marøy AG, MacKey J, Tekauz A, Penner GA, Bjørnstad A (2002) Genetic analysis of resistance to barley scald (Rhynchosporium secalis) in the Ethiopian line 'Abyssinian' (CI668).

Euphytica 126:235-250

Hahn M, Jungling S, Knogge W (1993) Cultivar-specific elicitation of barley defense reactions by the phytotoxic peptide NIP1 from Rhynchosporium secalis. Molecular plant-microbe interactions : MPMI 6:745-754

Hanemann A, Schweizer GF, Cossu R, Wicker T, Röder MS (2009) Fine mapping, physical mapping and development of diagnostic markers for the Rrs 2 scald resistance gene in barley. Theoretical and Applied Genetics 119:1507-1522

Hofmann K, Silvar C, Casas AM, Herz M, Büttner B, Gracia MP, Contreras-Moreira B, Wallwork H, Igartua E, Schweizer G (2013) Fine mapping of the Rrs1 resistance locus against scald in two large populations derived from Spanish barley landraces. Theoretical and Applied Genetics 126:3091-3102 Jackson LF, Webster RK (1976) Race Differentiation, Distribution, and Frequency of Rhynchosporium-Secalis in California. Phytopathology 66:719-725 
Kari AG, Griffiths E (1993) Components of partial resistance of barley to Rhynchosporium secalis: use of seedling tests to predict field resistance. Annals of Applied Biology 123:545-561

Khan T, Crosbie G (1988) Effect of scald (Rhynchosporium secalis (Oud.) J. Davis) infection on some quality characteristics of barley. Australian Journal of Experimental Agriculture 28:783-785

Kirsten S, Navarro-Quezada A, Penselin D, Wenzel C, Matern A, Leitner A, Baum T, Seiffert U, Knogge W (2012) Necrosis-inducing proteins of Rhynchosporium commune, effectors in quantitative disease resistance. Molecular plant-microbe interactions : MPMI 25:1314-1325

Lehnackers H, Knogge W (1990) Cytological studies on the infection of barley cultivars with known resistance genotypes by Rhynchosporium secalis. Canadian Journal of Botany 68:1953-1961 Looseley ME, Keith R, Guy D, Barral-Baron G, Thirugnanasambandam A, Harrap D, Werner P, Newton AC (2015) Genetic mapping of resistance to Rhynchosporium commune and characterisation of early infection in a winter barley mapping population. Euphytica 203:337-347

Looseley ME, Newton AC, Atkins SD, Fitt BDL, Fraaije BA, Thomas WTB, Keith R, Macaulay M, Lynott J, Harrap D (2012) Genetic basis of control of Rhynchosporium secalis infection and symptom expression in barley. Euphytica 184:47-56

Malosetti M, van Eeuwijk FA, Boer MP, Casas AM, Elía M, Moralejo M, Bhat PR, Ramsay L, Molina-Cano J-L (2011) Gene and QTL detection in a three-way barley cross under selection by a mixed model with kinship information using SNPs. Theoretical and Applied Genetics 122:1605-1616 Marzin S, Hanemann A, Sharma S, Hensel G, Kumlehn J, Schweizer G, Röder MS (2016) Are PECTIN ESTERASE INHIBITOR genes involved in mediating resistance to Rhynchosporium commune in barley? PLoS ONE 11:e0150485

Mascher M, Gundlach H, Himmelbach A, Beier S, Twardziok SO, Wicker T, Radchuk V, Dockter C, Hedley PE, Russell J, Bayer M, Ramsay L, Liu H, Haberer G, Zhang X-Q, Zhang Q, Barrero RA, Li L, Taudien S, Groth M, Felder M, Hastie A, Šimková H, Staňková H, Vrána J, Chan S, MuñozAmatriaín M, Ounit R, Wanamaker S, Bolser D, Colmsee C, Schmutzer T, Aliyeva-Schnorr L, Grasso S, Tanskanen J, Chailyan A, Sampath D, Heavens D, Clissold L, Cao S, Chapman B, Dai F, Han Y, Li H, Li X, Lin C, McCooke JK, Tan C, Wang P, Wang S, Yin S, Zhou G, Poland JA, Bellgard MI, Borisjuk L, Houben A, Doležel J, Ayling S, Lonardi S, Kersey P, Langridge P, Muehlbauer GJ, Clark MD, Caccamo M, Schulman AH, Mayer KFX, Platzer M, Close TJ, Scholz U, Hansson M, Zhang G, Braumann I, Spannagl M, Li C, Waugh R, Stein N (2017) A chromosome conformation capture ordered sequence of the barley genome. Nature 544:427-433

Massman J, Cooper B, Horsley R, Neate S, Dill-Macky R, Chao S, Dong Y, Schwarz P, Muehlbauer GJ, Smith KP (2011) Genome-wide association mapping of Fusarium head blight resistance in contemporary barley breeding germplasm. Molecular Breeding 27:439-454 
Mayer KF, Waugh R, Brown JW, Schulman A, Langridge P, Platzer M, Fincher GB, Muehlbauer GJ, Sato K, Close TJ, Wise RP, Stein N (2012) A physical, genetic and functional sequence assembly of the barley genome. Nature 491:711-716

Moragues M, Comadran J, Waugh R, Milne I, Flavell AJ, Russell JR (2010) Effects of ascertainment bias and marker number on estimations of barley diversity from high-throughput SNP genotype data. Theoretical and Applied Genetics 120:1525-1534

Muñoz-Amatriaín M, Moscou MJ, Bhat PR, Svensson JT, Bartoš J, Suchánková P, Šimková H, Endo TR, Fenton RD, Lonardi S, Castillo AM, Chao S, Cistué L, Cuesta-Marcos A, Forrest KL, Hayden MJ, Hayes PM, Horsley RD, Makoto K, Moody D, Sato K, Vallés MP, Wulff BBH, Muehlbauer GJ, Doležel J, Close TJ (2011) An improved consensus linkage map of barley based on flow-sorted chromosomes and single nucleotide polymorphism markers. The Plant Genome 4:238-249

Newton AC, Searle J, Guy DC, Hackett CA, Cooke DEL (2001) Variability in pathotype, aggressiveness, RAPD profile, and rDNA ITS1 sequences of UK isolates of Rhynchosporium secalis. Zeitschrift fur Pflanzenkrankheiten und Pflanzenschutz-Journal of Plant Diseases and Protection $108: 446-458$

Oliver RP, Ipcho SV (2004) Arabidopsis pathology breathes new life into the necrotrophs-vs.biotrophs classification of fungal pathogens. Mol Plant Pathol 5:347-352

Patil V, Bjørnstad Å, Mackey J (2003) Molecular mapping of a new gene Rrs4CI 11549 for resistance to barley scald (Rhynchosporium secalis). Molecular Breeding 12:169-183

Perfect SE, Green JR (2001) Infection structures of biotrophic and hemibiotrophic fungal plant pathogens. Mol Plant Pathol 2:101-108

Pickering R, Ruge-Wehling B, Johnston PA, Schweizer G, Ackermann P, Wehling P (2006) The transfer of a gene conferring resistance to scald (Rhynchosporium secalis) from Hordeum bulbosum into H. vulgare chromosome 4HS. Plant Breeding 125:576-579

Poland JA, Balint-Kurti PJ, Wisser RJ, Pratt RC, Nelson RJ (2009) Shades of gray: the world of quantitative disease resistance. Trends Plant Sci 14:21-29

Richards JK, Friesen TL, Brueggeman RS (2017) Association mapping utilizing diverse barley lines reveals net form net blotch seedling resistance/susceptibility loci. Theoretical and Applied Genetics 130:915-927

Rohe M, Gierlich A, Hermann H, Hahn M, Schmidt B, Rosahl S, Knogge W (1995) The race-specific elicitor, NIP1, from the barley pathogen, Rhynchosporium secalis, determines avirulence on host plants of the Rrs1 resistance genotype. The EMBO journal 14:4168-4177 
Schürch S, Linde CC, Knogge W, Jackson LF, McDonald BA (2004) Molecular population genetic analysis differentiates two virulence mechanisms of the fungal avirulence gene NIP1. Molecular Plant-Microbe Interactions 17:1114-1125

Schweizer G, Herz M, Mikolajewski S, Brenner M, Hartl L, Baumer M (2004) Genetic mapping of a novel scald resistance gene Rrs15CI8288 in barley. Proceedings of the 9th international barley genetics symposium, Brno, Czech Republic, pp 258-265

Schweizer GF, Baumer M, Daniel G, Rugel H, Roder MS (1995) RFLP markers linked to scald (Rhynchosporium secalis) resistance gene Rh2 in barley. Theor Appl Genet 90:920-924

Schweizer P, Stein N (2011) Large-scale data integration reveals colocalization of gene functional groups with meta-QTL for multiple disease resistance in barley. Molecular Plant-Microbe Interactions 24:1492-1501

Simko I, Piepho HP (2012) The area under the disease progress stairs: calculation, advantage, and application. Phytopathology 102:381-389

Taggart PJ, Locke T, Phillips AN, Pask N, Hollomon DW, Kendall SJ, Cooke LR, Mercer PC (1999) Benzimidazole resistance in Rhynchosporium secalis and its effect on barley leaf blotch control in the UK. Crop Protection 18:239-243

Tamang P, Neupane A, Mamidi S, Friesen T, Brueggeman R (2015) Association mapping of seedling resistance to spot form net blotch in a worldwide collection of barley. Phytopathology 105:500-508 Thirugnanasambandam A, Wright KM, Atkins SD, Whisson SC, Newton AC (2011) Infection of Rrs1 barley by an incompatible race of the fungus Rhynchosporium secalis expressing the green fluorescent protein. Plant Pathology 60:513-521

Thomas W, Comadran J, Ramsay L, Shaw P, Marshall D, Newton AC, O'Sullivan DM, Cockram J, Mackay IJ, Bayles R, White J, Kearsey M, Luo Z, Wang M, Tapsell C, Harrap D, Werner P, Klose S, Bury P, Wroth J, Argillier O, Habgood R, Glew M, Bochard A-M, Gymer P, Vequaud D, Christerson T, Allvin B, Davies N, Broadbent R, Brosnan J, Bringhurst T, Booer C, Waugh R (2014) Project Report No. 528: Association genetics of UK elite barley (AGOUEB). HGCA

Thomas WTB, Powell W, Waugh R, Chalmers KJ, Barua UM, Jack P, Lea V, Forster BP, Swanston JS, Ellis RP, Hanson PR, Lance RCM (1995) Detection of quantitative trait loci for agronomic, yield, grain and disease characters in spring barley (Hordeum vulgare L.). Theoretical and Applied Genetics 91:1037-1047

Tondelli A, Xu X, Moragues M, Sharma R, Schnaithmann F, Ingvardsen C, Manninen O, Comadran J, Russell J, Waugh R, Schulman AH, Pillen K, Rasmussen SK, Kilian B, Cattivelli L, Thomas WTB, Flavell AJ (2013) Structural and temporal variation in genetic diversity of European spring two-row 
barley cultivars and association mapping of quantitative traits. The Plant Genome 10.3835/plantgenome2013.03.0007

Tottman DR (1987) The decimal code for the growth stages of cereals, with illustrations. Annals of Applied Biology 110:441-454

van't Slot KA, Gierlich A, Knogge W (2007) A single binding site mediates resistance- and diseaseassociated activities of the effector protein NIP1 from the barley pathogen Rhynchosporium secalis. Plant Physiol 144:1654-1666

VSN International (2011) GenStat for windows 14th edition. VSN International, Hemel Hempstead, UK

Walters DR, Avrova A, Bingham IJ, Burnett FJ, Fountaine J, Havis ND, Hoad SP, Hughes G, Looseley M, Oxley SJP, Renwick A, Topp CFE, Newton AC (2012) Control of foliar diseases in barley: towards an integrated approach. European Journal of Plant Pathology 133:33-73

Waugh R, Flavell JA, Russell J, Thomas W, Ramsay L, Comadran J (2014) Exploiting barley genetic resources for genome wide association scans (GWAS). In: Tuberosa R, Graner A, Frison E (eds) Genomics of Plant Genetic Resources: Volume 1 Managing, sequencing and mining genetic resources. Springer Netherlands, Dordrecht, pp 237-254

Williams RJ, Owen H (1975) Susceptibility of barley cultivars to leaf blotch and aggressiveness of Rhynchosporium secalis races. Transactions of the British Mycological Society 65:109-114

Xi K, Xue AG, Burnett PA, Helm JH, Turkington TK (2000) Quantitative resistance of barley cultivars to Rhynchosporium secalis. Canadian Journal of Plant Pathology-Revue Canadienne de Phytopathologie 22:217-223

Xu X, Sharma R, Tondelli A, Russell J, Comadran J, Schnaithmann F, Pillen K, Kilian B, Cattivelli L, Thomas WTB, Flavell AJ (2018) Genome-wide association analysis of grain yield-associated traits in a pan-European barley cultivar collection. The Plant Genome 10.3835/plantgenome2017.08.0073

Xue G, Hall R (1991) Components of parasitic fitness in Rhynchosporium secalis and quantitative resistance to scald in barley as determined with a dome inoculation chamber. Canadian Journal of Plant Pathology 13:19-25

Yun S, Gyenis L, Bossolini E, Hayes P, Matus I, Smith K, Steffenson B, Tuberosa R, Muehlbauer G (2006) Validation of quantitative trait loci for multiple disease resistance in barley using advanced backcross lines developed with a wild barley. Crop Science 46:1179-1186

Zaffarano PL, McDonald BA, Zala M, Linde CC (2006) Global hierarchical gene diversity analysis suggests the fertile crescent is not the center of origin of the barley scald pathogen Rhynchosporium secalis. Phytopathology 96:941-950 
Zhan J, Fitt BDL, Pinnschmidt HO, Oxley SJP, Newton AC (2008) Resistance, epidemiology and sustainable management of Rhynchosporium secalis populations on barley. Plant Pathology 57:1-14 Zhan J, Yang L, Zhu W, Shang L, Newton AC (2012) Pathogen Populations Evolve to Greater Race Complexity in Agricultural Systems - Evidence from Analysis of Rhynchosporium secalis Virulence Data. PLOS ONE 7:e38611

Zhou H, Steffenson BJ, Muehlbauer G, Wanyera R, Njau P, Ndeda S (2014) Association mapping of stem rust race TTKSK resistance in US barley breeding germplasm. Theoretical and Applied Genetics $127: 1293-1304$

Ziems LA, Hickey LT, Hunt CH, Mace ES, Platz GJ, Franckowiak JD, Jordan DR (2014) Association mapping of resistance to Puccinia hordei in Australian barley breeding germplasm. Theoretical and Applied Genetics 127:1199-1212 
Table 1. Phenotypic correlation coefficients between measures of rhynchosporium severity and height. The significance of each correlation coefficient is indicated by asterisks, with a single, double and triple asterisks corresponding to $\mathrm{p}<0.05, \mathrm{p}<0.01$ and $\mathrm{p}<0.001$ respectively.

\begin{tabular}{|c|c|c|c|c|c|}
\hline \multirow[t]{2}{*}{ Trait } & \multicolumn{3}{|c|}{ AUDPC } & \multirow{2}{*}{$\begin{array}{c}\text { RL/NL } \\
\text { Mean }\end{array}$} & \multirow[t]{2}{*}{ Height 2014} \\
\hline & 2013 & 2014 & 2015 & & \\
\hline AUDPC 2013 & - & & & & \\
\hline AUDPC 2014 & $0.37 * * *$ & - & & & \\
\hline AUDPC 2015 & $0.53 * * *$ & $0.47 * * *$ & - & & \\
\hline RL/NL Mean & $0.33 * * *$ & $0.32 * * *$ & $0.39 * * *$ & - & \\
\hline Height 2014 & $-0.24 * * *$ & $-0.26 * * *$ & $-0.28 * * *$ & $-0.14 *$ & - \\
\hline Height 2015 & $-0.15 *$ & -0.11 & $-0.14 *$ & -0.11 & $0.56 * * *$ \\
\hline
\end{tabular}


Table 2. Summary of significant marker trait associations identified from a multi-environment GWAS using three years of disease nursery trials. Where multiple associated SNPs (at different positions) were detected for a QTL, the interval over which significant marker associations were identified is indicated. Where effects differ between years, evidence was found for a significant QTL by environment interaction, these are also indicated by an asterisk.

\begin{tabular}{|c|c|c|c|c|c|c|c|c|c|c|c|c|}
\hline \multirow[t]{2}{*}{ Trait } & \multirow{2}{*}{$\begin{array}{c}\text { QTL } \\
\text { Name }\end{array}$} & \multirow[t]{2}{*}{$\mathrm{Chr}$} & \multirow[t]{2}{*}{ Peak Marker } & \multirow{2}{*}{$\begin{array}{c}\text { Physical } \\
\text { position, bp }\end{array}$} & \multirow[t]{2}{*}{ Position (Interval), cM } & \multirow{2}{*}{$\begin{array}{c}\text { Alleles, } \\
\text { Major/ } \\
\text { minor }\end{array}$} & \multirow[t]{2}{*}{$\mathrm{MAF}^{\mathrm{a}}$} & \multirow[t]{2}{*}{$-\log _{10} p$} & \multicolumn{3}{|c|}{ Minor allele effect } & \multirow[t]{2}{*}{ GxE } \\
\hline & & & & & & & & & 2013 & 2014 & 2015 & \\
\hline \multirow{8}{*}{ 客 } & QA1 & $2 \mathrm{H}$ & SCRI_RS_155957 & $19,671,074$ & $21.3(18.6-21.3)$ & $\mathrm{A} / \mathrm{G}$ & 0.26 & 3.8 & $-0.13^{b}$ & 0.07 & 0.10 & $*$ \\
\hline & QA2 & $2 \mathrm{H}$ & SCRI_RS_138045 & $732,622,007$ & $136.8(133.3-136.8)$ & $\mathrm{A} / \mathrm{G}$ & 0.11 & 3.8 & 0.02 & $0.15^{\mathrm{b}}$ & $0.28^{\mathrm{b}}$ & $*$ \\
\hline & QA3 & $3 \mathrm{H}$ & SCRI_RS_221644 & $490,226,429$ & $53.5(47.2-59.6)$ & $\mathrm{A} / \mathrm{G}$ & 0.12 & 9.9 & $-0.57^{b}$ & $-0.57^{\mathrm{b}}$ & $-0.57^{b}$ & \\
\hline & QA4 & $3 \mathrm{H}$ & SCRI_RS_227898 & $564,870,387$ & $75.3(75.3-75.8)$ & $\mathrm{G} / \mathrm{A}$ & 0.22 & 4.2 & $-0.27^{\mathrm{b}}$ & $-0.27^{b}$ & $-0.27^{b}$ & \\
\hline & QA5 & $3 \mathrm{H}$ & SCRI_RS_138723 & $632,253,092$ & $112.2(112.2-118.7)$ & $\mathrm{T} / \mathrm{A}$ & 0.18 & 3.2 & $-0.22^{b}$ & $-0.22^{b}$ & $-0.22^{b}$ & \\
\hline & QA6 & $4 \mathrm{H}$ & SCRI_RS_197394 & $8,808,903$ & $14.3(14.3-14.3)$ & $\mathrm{T} / \mathrm{C}$ & 0.14 & 3.3 & -0.03 & -0.04 & $0.19^{\mathrm{b}}$ & $*$ \\
\hline & QA7 & $6 \mathrm{H}$ & SCRI_RS_201251 & $16,986,968$ & $25.7(24.2-25.7)$ & $\mathrm{G} / \mathrm{A}$ & 0.25 & 3.4 & 0.05 & 0.10 & $0.21^{\mathrm{b}}$ & $*$ \\
\hline & QA8 & $7 \mathrm{H}$ & SCRI_RS_138457 & $36,912,761$ & $29.7(18.5-29.9)$ & $\mathrm{A} / \mathrm{C}$ & 0.49 & 3.8 & $-0.19^{b}$ & $-0.19^{b}$ & $-0.19^{b}$ & \\
\hline \multirow{6}{*}{$\frac{20}{0.00}$} & QH1 & $2 \mathrm{H}$ & SCRI_RS_185319 & $22,770,072$ & $21.8(15.6-21.8)$ & $\mathrm{G} / \mathrm{C}$ & 0.15 & 6.4 & - & $3.04^{\mathrm{b}}$ & $1.66^{\mathrm{b}}$ & $*$ \\
\hline & $\mathrm{QH} 2$ & $2 \mathrm{H}$ & SCRI_RS_137263 & $653,415,617$ & 82.3 & $\mathrm{~A} / \mathrm{G}$ & 0.22 & 5.1 & - & $-2.55^{\mathrm{b}}$ & $-2.55^{\mathrm{b}}$ & \\
\hline & $\mathrm{QH} 3$ & $3 \mathrm{H}$ & $11 \_10601$ & $54,950,033$ & $47.2(47.2-47.4)$ & $\mathrm{A} / \mathrm{C}$ & 0.28 & 8.0 & - & $3.10^{\mathrm{b}}$ & $3.10^{\mathrm{b}}$ & \\
\hline & QH4 & $3 \mathrm{H}$ & SCRI_RS_138723 & $632,253,189$ & $112.2(102.2-123)$ & $\mathrm{T} / \mathrm{A}$ & 0.18 & 19.7 & - & $5.93^{\mathrm{b}}$ & $3.69^{\mathrm{b}}$ & * \\
\hline & QH5 & $6 \mathrm{H}$ & SCRI_RS_237419 & $399,378,996$ & $59.1(59.1-61.9)$ & $\mathrm{A} / \mathrm{G}$ & 0.41 & 5.7 & - & -0.81 & $1.89^{\mathrm{b}}$ & $*$ \\
\hline & QH6 & $7 \mathrm{H}$ & 1110209 & $260,601,407$ & $72(71.1-72)$ & $\mathrm{G} / \mathrm{A}$ & 0.47 & 5.6 & - & $2.34^{\mathrm{b}}$ & $2.34^{\mathrm{b}}$ & \\
\hline
\end{tabular}

${ }^{a}$ Minor allele frequency

${ }^{\mathrm{b}}$ Indicates that allelic differences were significant within year 
Table 3. Summary of significant marker trait associations identified from a single environment GWAS. Where multiple associated SNPs (at different positions) were detected for a QTL, the interval over which significant marker associations were identified is indicated.

\begin{tabular}{|c|c|c|c|c|c|c|c|c|c|}
\hline Trait & $\begin{array}{l}\text { QTL } \\
\text { Name }\end{array}$ & Chr & Peak marker & $\begin{array}{l}\text { Physical } \\
\text { interval, bp }\end{array}$ & $\begin{array}{l}\text { Genetic position } \\
\text { (interval), cM }\end{array}$ & $\begin{array}{l}\text { Alleles, } \\
\text { Major/ } \\
\text { minor }\end{array}$ & $\mathrm{MAF}^{\mathrm{a}}$ & $-\log _{10} p$ & $\begin{array}{l}\text { Minor } \\
\text { allele } \\
\text { effect }\end{array}$ \\
\hline \multirow{9}{*}{ 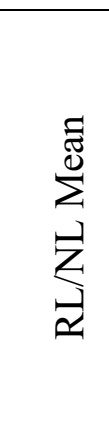 } & QI1 & $3 \mathrm{H}$ & SCRI RS 162639 & $22,299,565$ & 30.6 & $\mathrm{C} / \mathrm{T}$ & 0.10 & 3.8 & 1.11 \\
\hline & QI2 & $3 \mathrm{H}$ & SCRI RS 221644 & $490,226,429$ & $53.5(53.5-61.1)$ & $\mathrm{A} / \mathrm{G}$ & 0.17 & 6.3 & -1.35 \\
\hline & QI3 & $3 \mathrm{H}$ & SCRI_RS_189322 & $682,763,236$ & 148.8 & $\mathrm{~T} / \mathrm{C}$ & 0.30 & 5.7 & 0.95 \\
\hline & QI4 & $4 \mathrm{H}$ & SCRI_RS_7704 & $19,478,534$ & $26.2(26.2-31.2)$ & $\mathrm{C} / \mathrm{T}$ & 0.26 & 3.7 & 0.83 \\
\hline & QI5 & $4 \mathrm{H}$ & 1120289 & $462,325,035$ & $50(48.7-52)$ & $\mathrm{G} / \mathrm{A}$ & 0.41 & 4.2 & 0.73 \\
\hline & QI6 & $5 \mathrm{H}$ & SCRI_RS_204275 & $543,386,913$ & 78.3 & $\mathrm{C} / \mathrm{A}$ & 0.32 & 3.3 & 0.63 \\
\hline & QI7 & $5 \mathrm{H}$ & SCRI RS 235443 & $568,905,012$ & $96.9(96.8-96.9)$ & $\mathrm{C} / \mathrm{T}$ & 0.38 & 3.8 & 0.71 \\
\hline & QI8 & $7 \mathrm{H}$ & $112 \overline{14} 19$ & 737.055 & 0.0 & $\mathrm{G} / \mathrm{A}$ & 0.43 & 3.8 & 0.67 \\
\hline & QI9 & $7 \mathrm{H}$ & $12 \quad 20832$ & $628,962,539$ & $117.3(108.8-122)$ & $\mathrm{C} / \mathrm{G}$ & 0.23 & 4.3 & 0.84 \\
\hline
\end{tabular}

${ }^{a}$ Minor allele frequency 
Table 4. Location of previously reported genes or loci influencing resistance to Rhynchosporium commune.

\begin{tabular}{|c|c|c|c|c|c|c|}
\hline Gene & Reference & $\begin{array}{l}\text { Reference flanking } \\
\text { marker(s) }\end{array}$ & $\begin{array}{l}\text { Flanking 9k } \\
\text { markers }\end{array}$ & Chr & Physical interval, bp & Interval, cM \\
\hline Rrs1 & $\begin{array}{l}\text { (Hofmann et al. } \\
\text { 2013) }\end{array}$ & 11_0010-11_0823 & $\begin{array}{l}12 \_30609- \\
11 \_11401\end{array}$ & $3 \mathrm{H}$ & $\begin{array}{l}489,991,522- \\
491,895,585\end{array}$ & $48.7-59.6$ \\
\hline $\operatorname{Rrs} 2$ & $\begin{array}{l}\text { (Hanemann et al. } \\
\text { 2009) }\end{array}$ & $\begin{array}{l}\text { Acri_SNP9 - } \\
668 \bar{A} 17 \_ \text {11-2_SNP5* }\end{array}$ & $\begin{array}{l}12 \_20201- \\
12 \_31350\end{array}$ & $7 \mathrm{H}$ & $4,280,866-6,314,541$ & $0.8-1$ \\
\hline $\operatorname{Rrs} 3$ & $\begin{array}{l}\text { (Grønnerød et al. } \\
\text { 2002) }\end{array}$ & Hvm003-hvm068 & $\begin{array}{l}12-11077- \\
11-11513\end{array}$ & $4 \mathrm{H}$ & $\begin{array}{l}161,219,174- \\
574,543,534\end{array}$ & $50.8-65.7$ \\
\hline $\operatorname{Rrs} 4$ & (Patil et al. 2003) & HVM060-WG940 & $\begin{array}{l}11 \_20063- \\
12 \_30090\end{array}$ & $3 \mathrm{H}$ & $\begin{array}{l}576,629,513- \\
598,143,391\end{array}$ & $85.4-96.3$ \\
\hline $\operatorname{Rrs} 13$ & (Abbott et al. 1995) & ABG378-MWG916 & $\begin{array}{l}11 \_21032- \\
11 \_20052\end{array}$ & $6 \mathrm{H}$ & $\begin{array}{l}10,327,213- \\
29,107,331\end{array}$ & $10-40.5$ \\
\hline $\operatorname{Rrs} 14$ & (Yun et al. 2006) & [CHR START]-Bmac0213 & $\begin{array}{l}12^{-} 10420- \\
11 \_20371\end{array}$ & $1 \mathrm{H}$ & $0-12,990,947$ & $0-23$ \\
\hline $\operatorname{Rrs} 15 a$ & (Genger et al. 2005) & HVM49 & 12_20079 & $7 \mathrm{H}$ & $647,664,938$ & 136.1 \\
\hline $\operatorname{Rrs} 15 b$ & (Wagner et al. 2008) & GBM1281-GBM1121 & $\begin{array}{l}11 \_21377- \\
12 \_31284\end{array}$ & $2 \mathrm{H}$ & $\begin{array}{l}11,188,932- \\
22,398,480\end{array}$ & $8.5-15.6$ \\
\hline $\operatorname{Rrs} 16$ & $\begin{array}{l}\text { (Pickering et al. } \\
2006)\end{array}$ & MWG634-scsnp00600 & $\begin{array}{l}12-31324- \\
11 \_11136\end{array}$ & $4 \mathrm{H}$ & $639,959-11,733,569$ & $0.7-19.6$ \\
\hline$s d w-1$ & $\begin{array}{l}\text { (Malosetti et al. } \\
\text { 2011) }\end{array}$ & BOPA1_11_10867* & $\begin{array}{l}12-11338- \\
12 \_30096\end{array}$ & $3 \mathrm{H}$ & $\begin{array}{l}632,252,063- \\
634,923,676\end{array}$ & $118.7-119.5$ \\
\hline
\end{tabular}

*Diagnostic markers 
Table 5. Resistance associated allele proportion compared to year of introduction for QTL associated with known major resistance genes and $s d w 1$. In the case of $s d w 1$, the frequency of the allele associated with the tall phenotype is indicated.

\begin{tabular}{|c|c|c|c|c|c|c|c|c|}
\hline Marker & Colocalised gene & $1970-1980$ & $1980-1990$ & $1990-1995$ & $1995-2000$ & $2000-2005$ & $2005-2010$ & 2010- 2014 \\
\hline SCRI_RS_201251 & $\operatorname{Rrs} 13$ & 0.56 & 0.73 & 0.75 & 0.81 & 0.69 & 0.81 & 0.78 \\
\hline SCRI_RS_197394 & $\operatorname{Rrs} 16$ & 0.83 & 0.76 & 0.81 & 0.9 & 0.93 & 0.94 & 0.97 \\
\hline SCRI_RS_138723 & $s d w 1$ & 0.83 & 0.36 & 0.11 & 0.09 & 0.02 & 0 & 0 \\
\hline
\end{tabular}


Table 6. Disease reactions of selected barley lines against two Rhynchosporium commune isolates, expressing NIP1. The name (or identifier) of each line is shown, with text in brackets indicating known major resistance genes carried by the line from published studies. Mean disease scores against isolates LfL12F and R214 are shown, with standard deviation between reps indicated in brackets. For tests of homogeneity, lines with a mean disease score less than 2 were considered resistant. The allele carried at marker SCRI_RS_221644 is indicated (allele ' $G$ ' was associated with the resistant phenotype in disease nursery trials).

\begin{tabular}{|c|c|c|c|c|c|}
\hline \multirow[t]{2}{*}{ Line } & \multicolumn{3}{|c|}{ Disease reaction } & \multirow{2}{*}{$\begin{array}{l}\text { SCRI_RS_221644 } \\
\text { allele }\end{array}$} & \multirow{2}{*}{$\begin{array}{l}\text { Seasonal } \\
\text { Habit }\end{array}$} \\
\hline & $\begin{array}{l}\text { LfL12F } \\
\text { mean (SD) }\end{array}$ & $\begin{array}{l}\text { R214 } \\
\text { Mean } \\
\text { (SD) }\end{array}$ & $\begin{array}{l}\text { T-R214- } \\
\text { GFP }\end{array}$ & & \\
\hline $\begin{array}{l}\mathrm{SBCC154} \\
\left(\operatorname{Rrs} 1_{R h 4}\right)\end{array}$ & 0.0 & - & Resistant & G & Spring \\
\hline $\begin{array}{l}\mathrm{SBCC} 145 \\
\left(\operatorname{Rrs} 1_{R h 4}\right)\end{array}$ & 0.0 & - & Resistant & $\mathrm{G}$ & Spring \\
\hline Acclaim & 0.0 & - & Resistant & $\mathrm{G}$ & Spring \\
\hline Beryllium & $0.4(0.4)$ & - & Resistant & $\mathrm{G}$ & Spring \\
\hline Brahms & 0.0 & - & Resistant & $\mathrm{G}$ & Spring \\
\hline Cairn & 0.0 & - & Resistant & G & Spring \\
\hline Casino & $0.3(0.6)$ & - & Resistant & $\mathrm{G}$ & Spring \\
\hline Celebra & 0.0 & - & Resistant & G & Spring \\
\hline Century & 0.0 & - & Resistant & $\mathrm{G}$ & Spring \\
\hline Chieftain & 0.0 & - & Resistant & $\mathrm{G}$ & Spring \\
\hline Corgi & 0.0 & - & Resistant & $\mathrm{G}$ & Spring \\
\hline Franklin & $0.8(0.3)$ & - & Resistant & $\mathrm{G}$ & Spring \\
\hline Gairdner & 0.0 & - & Resistant & $\mathrm{G}$ & Spring \\
\hline Graphic & 0.0 & - & Resistant & $\mathrm{G}$ & Spring \\
\hline Retriever & 0.0 & - & Resistant & $\mathrm{G}$ & Winter \\
\hline SW Macsena & 0.0 & - & Resistant & $\mathrm{G}$ & Spring \\
\hline Westminster & 0.0 & - & Resistant & $\mathrm{G}$ & Spring \\
\hline Chronicle & 0.0 & - & - & $\mathrm{G}$ & Spring \\
\hline Freja & 0.0 & - & - & $\mathrm{G}$ & Spring \\
\hline Magellan & 0.0 & - & - & $\mathrm{G}$ & Spring \\
\hline Rebecca & $0.3(0.6)$ & - & - & $\mathrm{G}$ & Spring \\
\hline Karri & $3.9(0.1)$ & - & - & $\mathrm{G}$ & Spring \\
\hline Acrobat & $3.6(0.7)$ & - & Susceptible & $\mathrm{A}$ & Spring \\
\hline Alexis & $4.0(0.0)$ & $3.3(1.3)$ & Susceptible & A & Spring \\
\hline Akita & $3.4(0.9)$ & - & Susceptible & A & Spring \\
\hline Apex & $3.8(0.2)$ & - & Susceptible & A & Spring \\
\hline Ardila & $3.5(0.7)$ & - & Susceptible & A & Spring \\
\hline Atlas & $2.5(1.2)$ & - & Susceptible & A & Spring \\
\hline Barabas & $3.6(0.1)$ & - & Susceptible & A & Spring \\
\hline Beatrix & $3.6(0.5)$ & $4.0(0.0)$ & Susceptible & A & Spring \\
\hline Bulbul 89 & $2.3(0.9)$ & - & Susceptible & A & Spring \\
\hline Concerto & $3.3(1.0)$ & - & Susceptible & A & Spring \\
\hline Gizmo & $3.8(0.3)$ & - & Susceptible & A & Spring \\
\hline
\end{tabular}




\begin{tabular}{|c|c|c|c|c|c|}
\hline Imidis & $3.1(0.5)$ & - & Susceptible & $\mathrm{A}$ & Spring \\
\hline Nordal & $4.0(0.0)$ & - & Susceptible & A & Spring \\
\hline Optic & $2.2(0.7)$ & - & Susceptible & A & Spring \\
\hline Cropton & $4.0(0.0)$ & - & - & A & Spring \\
\hline Aapo & $3.3(0.9)$ & - & - & A & Spring \\
\hline Abava & $3.2(0.8)$ & - & - & A & Spring \\
\hline Annabel & $3.8(0.5)$ & - & - & A & Spring \\
\hline Aspen & $3.6(0.2)$ & - & - & A & Spring \\
\hline Atem & $3.5(0.4)$ & - & - & A & Spring \\
\hline Athena & $3.5(0.5)$ & - & - & $\mathrm{A}$ & Spring \\
\hline Azure & $3.3(0.3)$ & - & - & $\mathrm{A}$ & Spring \\
\hline Baronesse & $3.8(0.2)$ & - & - & A & Spring \\
\hline Binder Abed & $3.0(0.4)$ & - & - & $\mathrm{A}$ & Spring \\
\hline Calgary & $2.6(0.4)$ & - & - & A & Spring \\
\hline Chamant & $3.7(0.6)$ & - & - & $\mathrm{A}$ & Spring \\
\hline Chaser & $3.2(0.3)$ & - & - & A & Spring \\
\hline $\begin{array}{l}\text { Chevallier } \\
\text { Tystofte }\end{array}$ & $3.1(0.7)$ & - & - & A & Spring \\
\hline CPBT_C80 & $2.9(1.0)$ & - & - & A & Spring \\
\hline Drum & $3.6(0.4)$ & - & - & A & Spring \\
\hline Felicitas & $3.6(0.4)$ & - & - & A & Spring \\
\hline Frieda & $3.2(0.4)$ & - & - & A & Spring \\
\hline Hannchen & $3.1(1.1)$ & - & - & A & Spring \\
\hline Harriot & $3.4(0.6)$ & - & - & $\mathrm{A}$ & Spring \\
\hline Ida & $3.9(0.1)$ & - & - & A & Spring \\
\hline Jive & $2.5(0.3)$ & - & - & A & Spring \\
\hline Klaxon & $3.2(0.1)$ & - & - & A & Spring \\
\hline Kym & $3.8(0.4)$ & - & - & A & Spring \\
\hline NSL 95-1257 & $3.6(0.5)$ & - & - & $\mathrm{A}$ & Spring \\
\hline NSL 98_5065 & $3.9(0.1)$ & - & - & $\mathrm{A}$ & Spring \\
\hline A96-10 $\overline{3}$ & $3.2(0.7)$ & - & - & $\mathrm{A}$ & Spring \\
\hline Rangoon & $3.8(0.0)$ & - & - & $\mathrm{A}$ & Spring \\
\hline Scarlett & $2.5(0.6)$ & - & - & A & Spring \\
\hline Steffi & $3.6(0.4)$ & $3.1(1.2)$ & - & A & Spring \\
\hline Tarm 92 & $3.1(0.4)$ & - & - & A & Facultative \\
\hline Vegas & $2.3(0.3)$ & - & - & $\mathrm{A}$ & Spring \\
\hline Vortex & $3.1(1.0)$ & - & - & A & Spring \\
\hline Pewter (Rrs2) & $1.6(0.7)$ & $3.5(0.0)$ & - & A & Spring \\
\hline
\end{tabular}

\section{Figure legends}

Figure 1. Representative images showing infection types in both of the controlled environment tests used in this study. The upper two panels show resistant (A) and susceptible (B) interactions as determined by detached leaf assay and confocal microscopy at 2 days post inoculation (dpi) with a GFP expressing Rhynchosporium commune isolate (T-R214-GFP). Green colour represents GFP fluorescence and shows fungal spores and hyphae, with blue 
colour showing chlorophyll auto-fluorescence. Resistant interactions typically show germinated spores, less extensive hyphal networks, with random growth directions, whilst resistant lines show much more extensive growth following the anticlinal wall of the epidermal cells. The lower panel (C) shows representative leaves illustrating the 0-4 scale used to quantify symptom expression 16 days post-inoculation (dpi) of 3 weeks old barley seedlings with a $2 \mathrm{x}$ $10^{5}$ spores $/ \mathrm{ml}$ suspension of $R$. commune. 0 represents an absence of visible disease symptoms (not shown) and 4 represents total collapse and drying-out of the entire leaf. Leaves with score of 2 and higher were considered susceptible.

Figure 2. Distribution of phenotypic scores for each of the trait/year combinations examined in this study. AUDPC in disease nursery trials (calculated from disease severity scores on a 19 scale) in A: 2013, B: 2014, C: 2015; D: disease severity estimates from historical Recommended List/National List (RL/NL) trial data; height (to the base of the ear after stem elongation had ceased) in disease nursery trials in E: 2014, F: 2015.

Figure 3. Manhattan plots showing association between genetic markers and the traits examined in this study expressed in $-\log 10 \mathrm{p}$. A: multi-environment GWAS using three years of disease severity scores from recent disease nursery trials. B: single-environment GWAS using predicted line means from UK Recommended List/National List (RL/NL) trial data. C: multi-environment GWAS using two years of height scores taken from recent disease nursery trials. Dotted lines indicate the thresholds chosen for selecting putative QTL effects for each trait. For the two disease scores, this is 3.2, representing a genome wide significance level of 0.05. For height, a higher threshold of 5 was used to reflect the higher median inflation factor. The positions of known genes or QTL influencing resistance to $R$. commune are highlighted as light grey bars (indicating an interval), or vertical dashed lines (indicating a position), with names given above the plots. D-F: Observed quantiles of the p-values for each of the GWAS analyses are plotted against their null distribution for datasets in $A-C(Q-Q)$ plots. For each plot, the dashed line represents equality between the observed and expected p-value, and the shaded region represents the $95 \%$ confidence interval of the expected values. 


\section{Supplementary Data}

Table S1. Details of the field trials conducted for the GWAS analyses. For each trial, the dimensions of the plot and sowing rates are indicated along with the date that the trial was sown. The dates are shown for each of the phenotypic assessments.

Table S2. Details of the lines used in the GWAS experiments. The name is indicated along with the AFP code and year that the line was first entered for National List trialling (NL1) where known. AUDPC scores are indicated for each of the disease nursery trials as well as the Recommended List/National List (RL/NL) mean.

Figure S1. A Principal Component Analysis plot of the genotypic data from the 601 genotyped lines used in this study, showing scores for the first two principal components. Figures in brackets following the axis labels indicate the percentage of the total genotypic variation accounted for by the corresponding principal component. 